\title{
Mentoring and Training in Developing Gunung Ireng Geotourism, Patuk District, Gunungkidul Regency, Yogyakarta Special Region
}

Sri Mulyaningsih ${ }^{1 *}$, Dina Tania ${ }^{1}$, Nurwidi Astanto Agus Tri Heriyadi ${ }^{1}$, Suhartono ${ }^{2}$

${ }^{1}$ Geology Engineering Study Program, Faculty of Mineral Technology, Institut Sains \& Teknologi AKPRIND, Yogyakarta, Indonesia

${ }^{2}$ Industrial Engineering, Faculty of Science and Technology, Universitas Widya Mataram, Yogyakarta, Indonesia

Submitted: November $8^{\text {th }}$ 2020; Revised: Octomber 20 ${ }^{\text {th }}$ 2021; Accepted: November $18^{\text {th }} 2021$

Keywords:
Development
Geotourism
Local
community
Mentoring

\begin{abstract}
Gunung Ireng geosite is an excellent geoheritage that is also a part of the Gunungsewu UNESCO Global Geopark in Pengkok, Gunungkidul Regency. It is widely recognized as an experiential leisure tour destination with the sunrise, sunset, and milky way watching as its activities. The primary attraction is the natural museum of Tertiary submarine paleo-volcanic miniature that was developed during the Early Miocene $( \pm 20-23$ million years ago). Mentoring in utilizing the resources is necessary. The local community has agreed to develop geotourism as an effort to conserve the cultural, biotic, and geological environment. The certified instructors or mentors and professionals used mentoring methods to increase the local community's abilities in preparing, managing, and evaluating the geotourism, including management, advertisement, marketing, guidance, web hosting, culinary, and accommodations.. The results are the status of the geoheritage area (by the Ministry of Energy and Mineral Resources No. 13 K.HK.01.MEM.G.2021), the viral of the local Gunung Ireng's Spot Festival, the local culinary facilities, the CHSE certificate, as well as up to $300 \%$ increase in visitors per month before the pandemic and $200-300 \%$ increase during the pandemic. Other results that have successfully developed the supporting attractions are the Ahad Pon traditional market, the footsteps flashback of the great da'wah Sunan Kalijogo on Gunung Ireng and the Geological Natural Track of the Ancient Volcano of Gunung Ireng. Those three attractions are the efforts to improve the local community's economy, nature, and cultural conservation as the solid implementations of geotourism activities. Qualitatively, these various efforts are now starting to show impacts, with the increased motivation of the community to focus more on developing this destination, and the increasing attention of local governments to support these conservation activities, although quantitatively it has not to be measured yet.
\end{abstract}

\section{INTRODUCTION}

Gunung Ireng is located at Srumbung, Pengkok Village, Patuk Subdistrict, Gunungkidul Regency, Yogyakarta Special Region, Indonesia (Figure 1.a; Figure 1.b). Gunung Ireng and its surroundings have been studied geologically, and it has been recognized as a Tertiary submarine paleovolcano (Blessia et., 2019; Mulyaningsih et al., 2019a; Mulyaningsih et al., 2019b). The research findings have been disseminated considering the specific scientific geotope and decided to be utilized as a special interest geotourism of the Natural Ancient Volcanic Museum.

Gunung Ireng has an exotic view in the morning. The visitors can feel as though they are standing on an island until sunrise occurs. It has an ellipsoidal dome, surrounded by a circular valley (Figure 1.a; Figure 1.b; Figure 1.c; Figure 1.d), which is regarded as a lava

ISSN 2460-9447 (print), ISSN 2541-5883 (online)

${ }^{*}$ Corresponding author: Sri Mulyaningsih

Department of Geological Engineering, Faculty of Mineral Technology, Institut Sains \& Teknologi AKPRIND, Jl. Kalisahak No. 28, Yogyakarta 55222, Indonesia

Email: sri_m@akprind.ac.id 

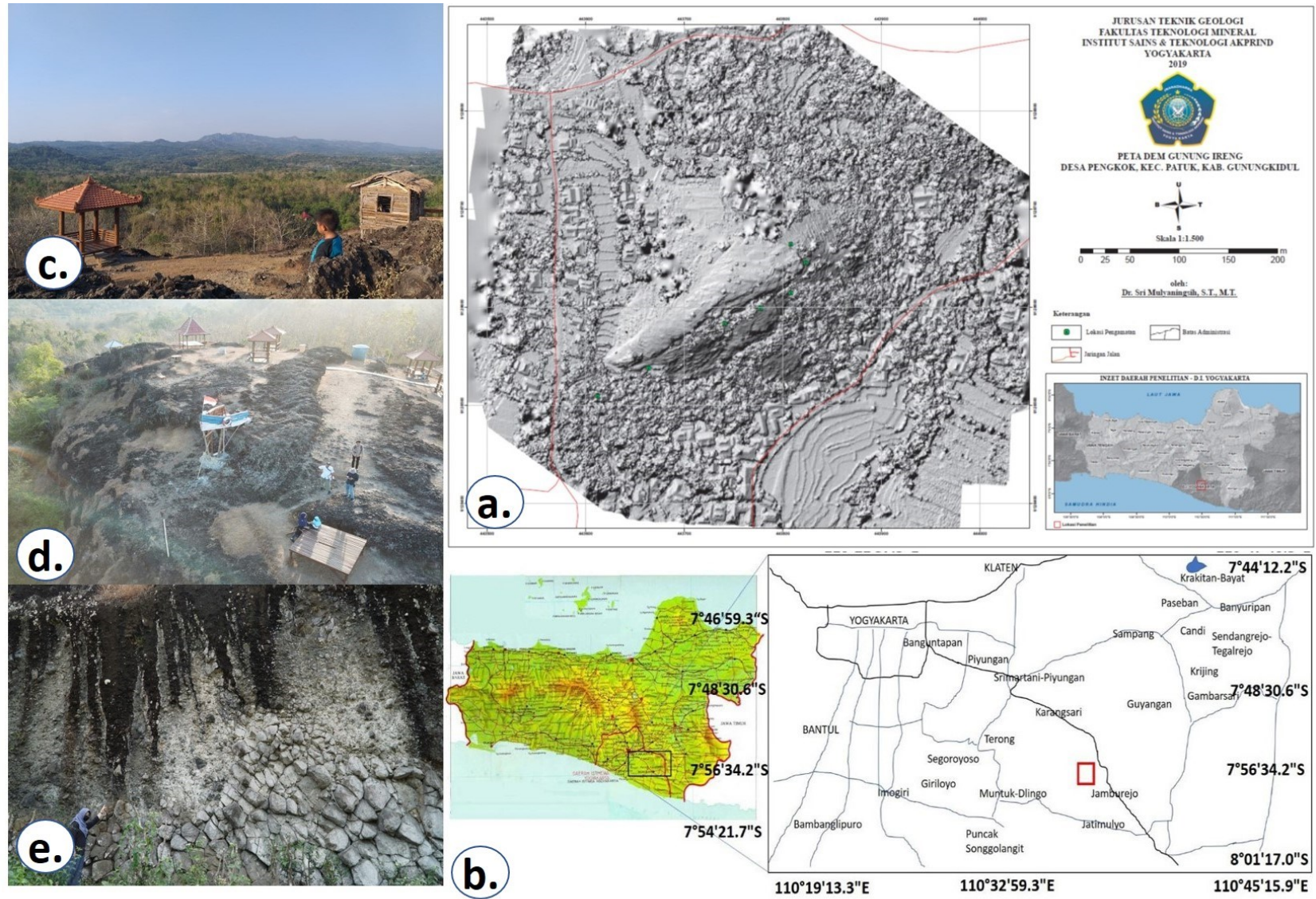

Figure 1. a) The ellipsoidal dome of Gunung Ireng that is surrounded by a circular valley; b) Situation map of Gunung Ireng Geotourism destination, located at Gunungkidul Regency, Yogyakarta Special Region and its geotourism potentials

dome in the paleo-caldera, similar to the crater and lava dome of the Galunggung Volcano in the present day. After that, the visitors can enjoy a cup of coffee and a bowl of boiled soup provided by the management. The rising sun brushed the mist beneath Gunung Ireng, revealing another panorama represented by the circular valley of the former caldera. The walls of Gunung Ireng, which were carved tectonically after volcanism, clearly reveal the geological data as one of the most complete volcanic miniatures in Java (Mulyaningsih et al., 2021). It consists of a vent and the wall, crater and the materials, as well as the tectonic fault and the basement rocks, which can provide educational meaning. The local cultures have developed Wong Ireng dance, Jathilan, Sunan Kalijogo's Footsteps, and others, which are only performed during village events.

Geotourism is an effort in conservation activities (cultural, biotic, and geological/abiotic), educating, and improving the economy of local communities (Bentivenga et al., 2019; Dowling \& Newsome, 2010). It requires the ability to interpret, which combines cultural, biotic, and abiotic explanations (Mulyaningsih et al., 2021; Rizkyaputri, 2021). Academicians can assist in accelerating and maintaining sustainability. This service activity was intended to help the managers in developing a geotourism destination named the Natural Geological Museum of the Tertiary Submarine Ancient Volcano. The purpose was to conserve, educate, increase visitors, and then extend the circulation of money. Adequate $5 \mathrm{~A}$ (facilities and infrastructure: activities, attractions, accessibility, accommodations, and amenities) are provided for a longer flow of money. This activity was approached with the assistance in obtaining these facilities, including an access to the local governments (funding, infrastructure, and other mentoring), networking with other destinations and additional supporting facilities, as well as management and guidance training.

\section{METHOD}

Gunung Ireng, as a geotourism destination, needs support from the local governments and the stakeholders. At the beginning of the activity, it was introduced to the local government and the president of Gunung Sewu Global Geopark (UGG) in the middle of 2019 (Figure 2.a). In addition, this activity also aimed to permit the local government and the management of UGG Gunung Sewu to prepare geoheritage documents to be proposed to the Geological Agency of DESDM (Figure 2.b), as the authorized party in assessing the proposed document for determining geoheritage areas. The assessment was done in early March 2020.

The next step was to improve the local community's economy to be the management. Various training was conducted to boost skills in tourism, including the management and preparation of amenities, accommodations, attractions, and activities 


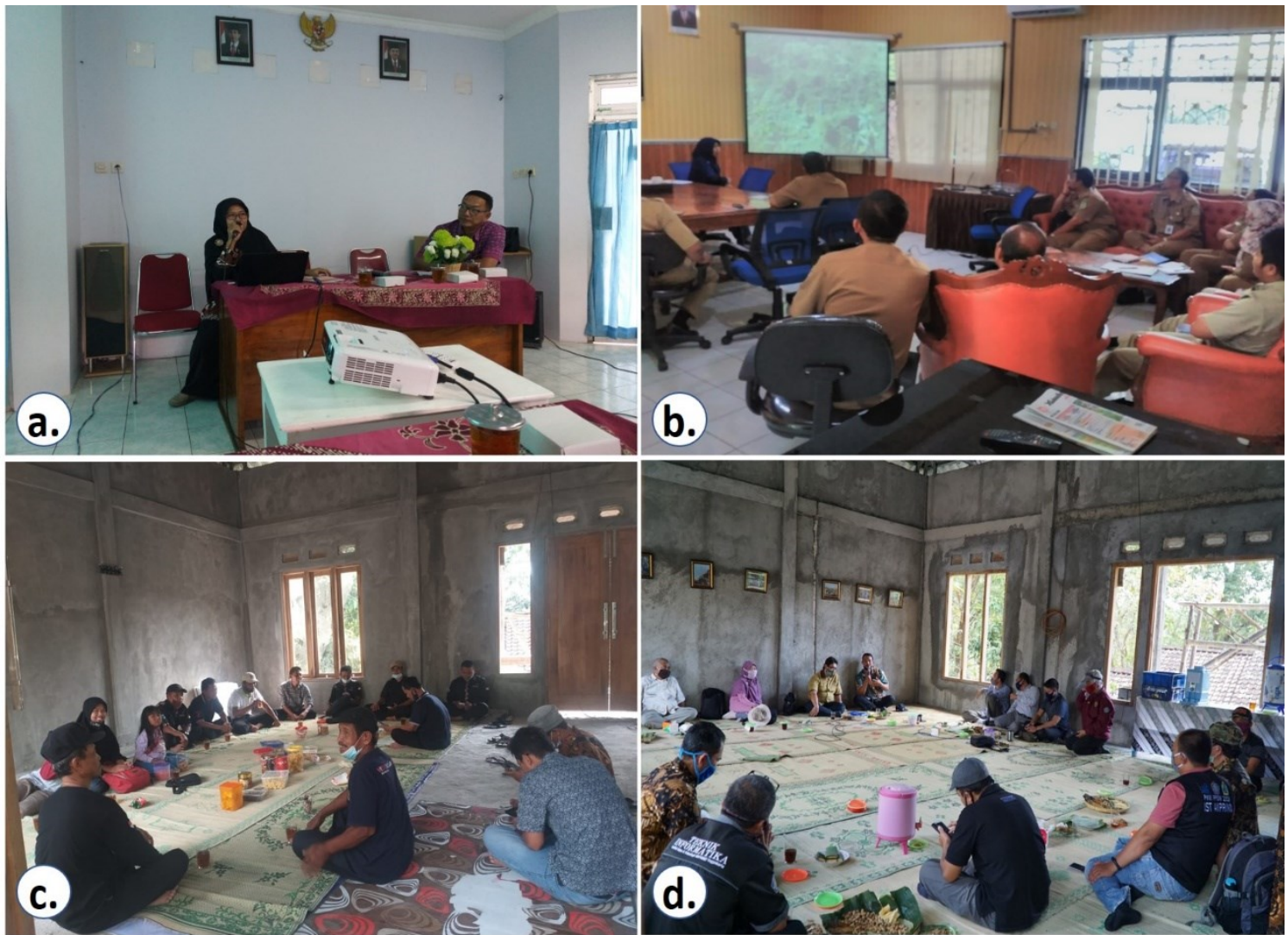

Figure 2. a) Presenting the results of research into the local government (May, 2019); b) Discussing the geotourism development with the Regional Research, Planning and Development Agency of Gunungkidul Regency (Juni 2019); c) Discussing the geotourism plan with the local community (June 2019); and d) Discussing the geotourism progress with the stakeholders and the local government (June 2021).

(Figure 2.c). The progress of Gunung Ireng is evaluated every Sunday night to explore the obstacles faced and brainstorm the best solution. (Figure 2.d). Organizational strengthening (POKDARWIS) is always monitored effectively, followed by planning activities in line with the vision, mission, and objectives of the Gunung Ireng Geotourism.

Training in geotourism management was conducted many times. The syllabus covered a community-based management system, website, culinary and lodging, marketing and promoting techniques, as well as geotorism guidance. This stage took two years (2020-2021). This training was conducted with instructors from HPI (Indonesian Tour Guide Association), IAGI (Indonesian Association of Geologists), academics, and practitioners. The training technique was conducted directly in class, followed by participation in the POKDARWIS competition at the Regency level. The Community Service Team, in collaboration with the Village Government, provided assistance in all activities, including finding instructors and facilitating them. The training participants were screened and selected to attract their interest and enthusiasm. Participants were sometimes brought in from other destinations that have a network with Gunung Ireng, such as geotourism guidance.

Another method of service activity was the provision of supporting facilities, such as geotourism signboards, routers and Wi-Fi (internet network), facilities for documentation (cameras and drones), and buffet bouquet equipment. People assigned to develop documentation were first taught how to use the tools to comply with procedures, techniques for taking pictures (photography), and presenting them until they were published on social media and websites. Comparative studies with other destinations have also been conducted to increase the element of amenities in Gunung Ireng. One of them was a study visit at the Sor Jati Traditional Market in Imogiri, a visit to Muntilan to learn how to make soap carving souvenirs, and a visit to orchid cultivation in Gamping (Sleman). The team gathered the community (managers) in the study activities.

\section{RESULT AND DISCUSSION}

The key to the success of a tourism destination development is an excellent, well-documented, and accountable management, supported by good organization and governance Management training and assistance had resulted in second place in the POKDARWIS competition on Gunungkidul Regency 2020. This result has motivated the managers and the community. Following the championships, the regional and provincial governments' attention on the progress of Gunung Ireng has continued to flow.

The first result obtained by Gunung Ireng is the legality of the geoheritage predicate which has been 


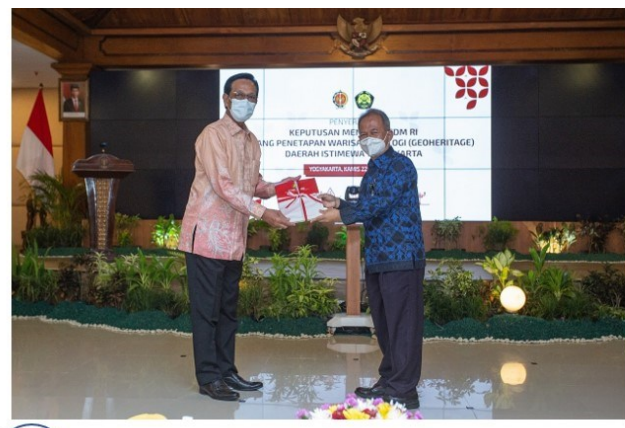

(a.)

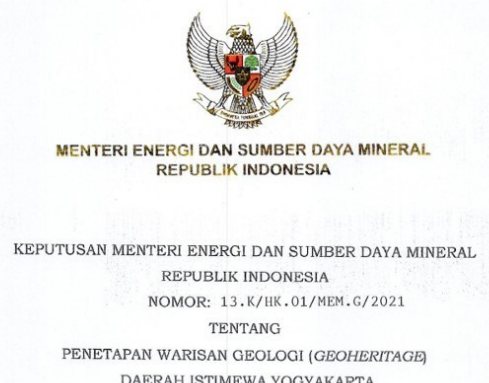
DAERAH ISTIMEWA YOGYAKARTA

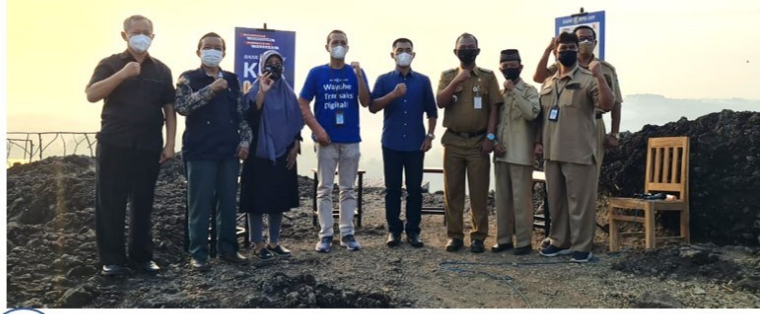

(b.)

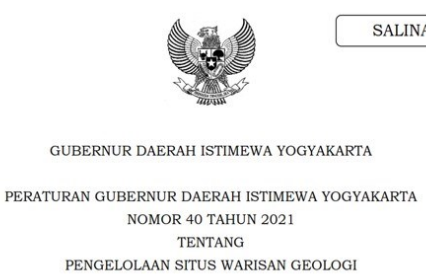

DENGAN RAHMAT TUHAN YANG MAHA ESA

GUBERNUR DAERAH ISTIMEWA YOGYAKARTA,

Figure 3. a. The Submission of Decree of the Minister of Energy and Mineral Resources Number 13 K.HK.01.MEM.G.2021 regarding the annihilation of 20 Geoheritage Sites in DI Yogyakarta by the Head of the Geological Agency to the Governor of DIY on 22 April 2021 (ESDM, 2021) and a copy of the decree; b) Pledge of commitment by the Gunungkidul Regent and the Head of the Gunungkidul BPD Bank in their commitment to maintaining and implementing the DIY governor's regulations regarding the use of geoheritage areas, one of which is Gunung Ireng and a copy of the governor's regulation No. 40 year 2021
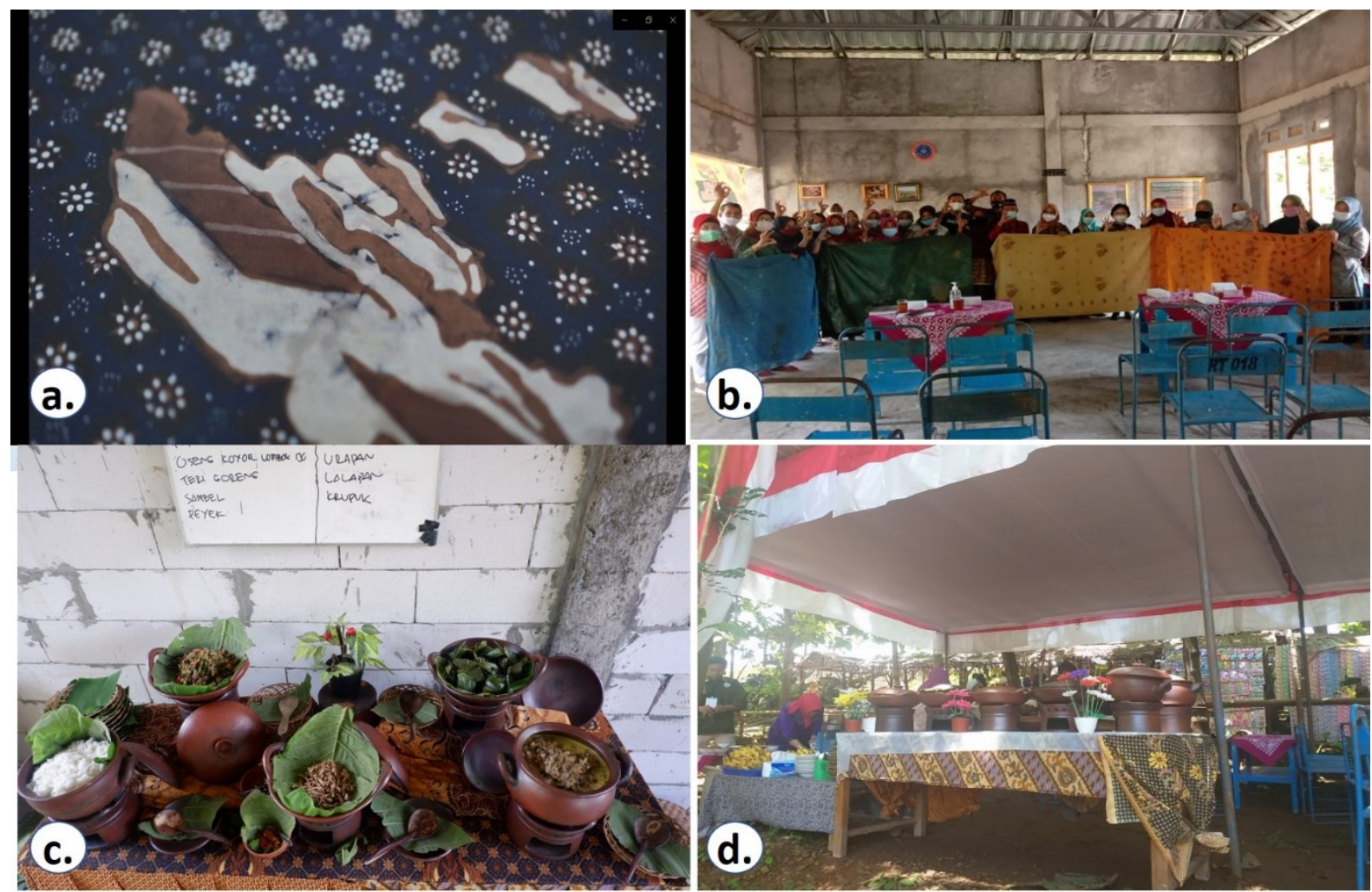

Figure 4. Some of the amenities that have been successfully added during the activity: a) The aesthetic Gunung Ireng's batik developed using local andesitic thin section motif (photo taken in 2019); b) The batik's implementation (photo taken in April 2021); c) Various menus that available at Gunung Ireng (photo taken on 2020, 9 January); d) Cafes and restaurants by order (photo taken on 2020, 10 March)

issued by the Ministry of Energy and Mineral Resources Number 13 K.HK.01.MEM.G.2021 (Figure 3.a), which is then followed up with the Regulation of the Governor of the Special Region of Yogyakarta
Number 40 of 2021 to be utilized optimally (Figure 3.b). The Tourism Office of Gunungkidul Regency has followed up this regulation by preparing various basic needs for Gunung Ireng, including various 
handwashing and health facilities, training and certification based on Indonesian National Competency Standards with the SKKNI scheme for Geotourism, and care to protect COVID-19 (CHSE) certification. The Gunungkidul Regency Public Works Office has followed it up as well by providing adequate road access from various surrounding destinations, from Patuk District to the location. The Regent of Gunungkidul is highly committed to the sustainability of this community service activity. The implementation of the Corporate Social Responsibility (CSR) program from the Regional Government Bank (BPD) of the

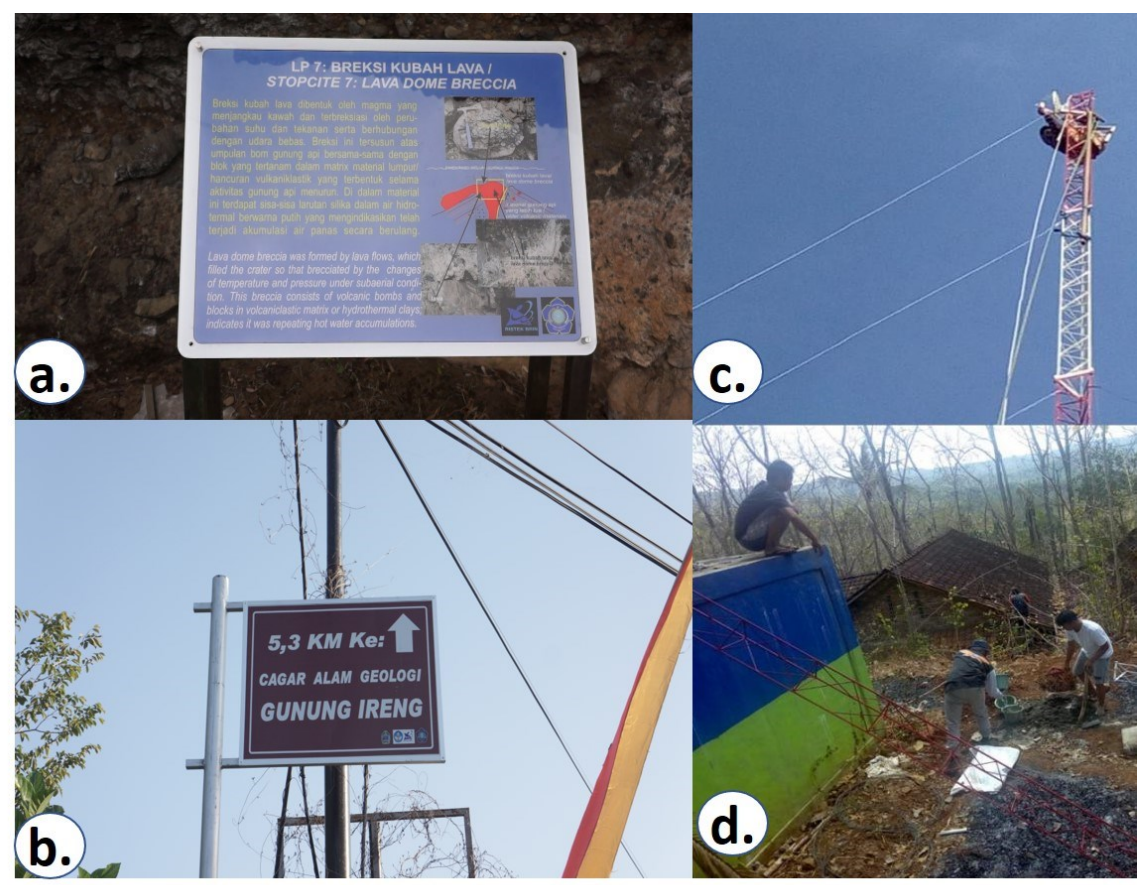

Figure 5. a) An example of a signboard installed at the Ancient Volcanic Museum (June 2021); b) The directional signboard (June 2021); c) Unlimited Microtik Wi-Fi (October 2019); d) Cultural signboard installation (October 2021)

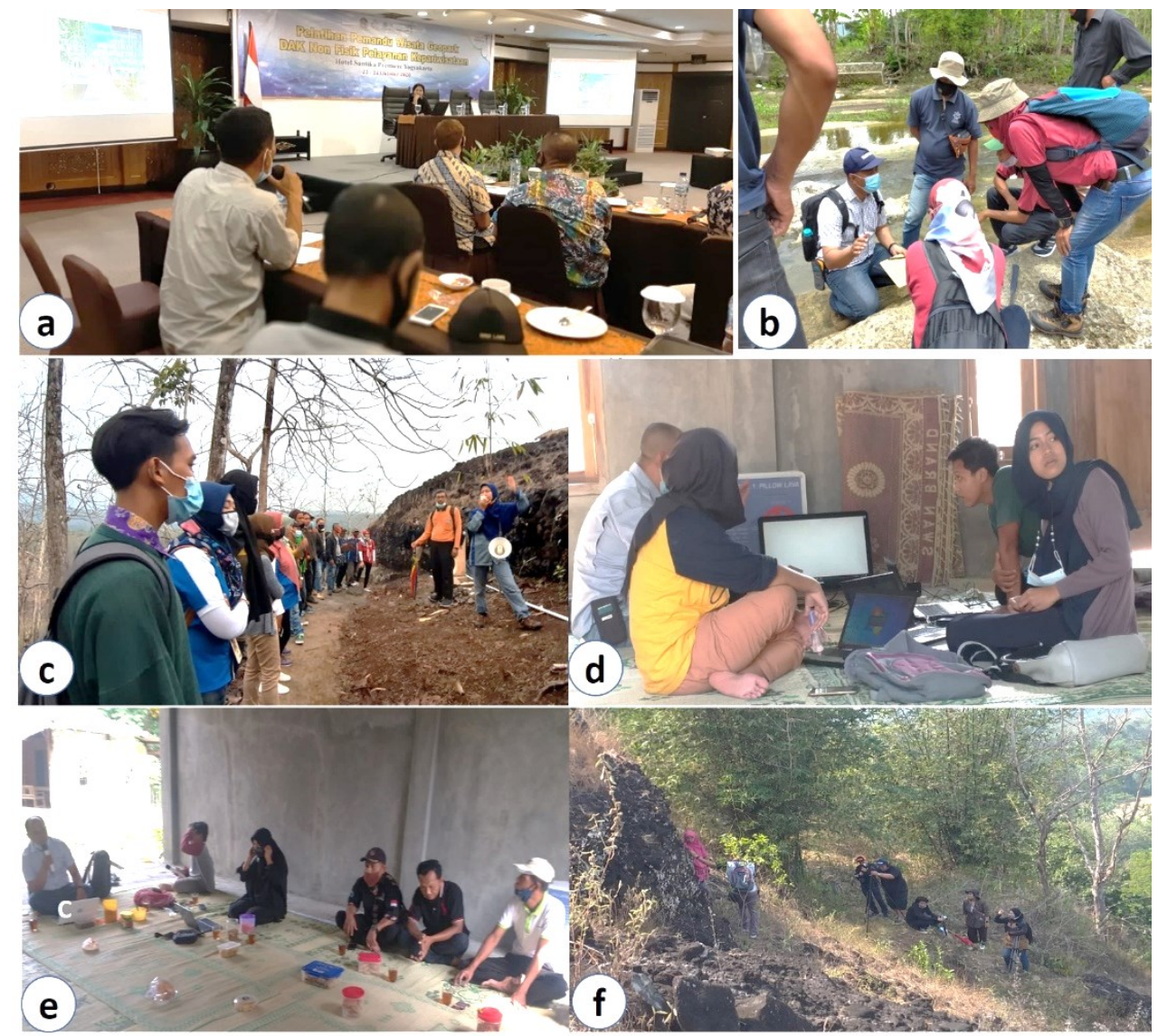

Figure 6. a) Classroom on geotourism guidance training (photo on October 2019); b) Training on interpretation tecniques (photo on October 2020); c) Intensive training on fieldwork guidance (photo on October 2021); d) Training on website and operating system (photo on May 2021); e) Motivation and mentoring on networking (photo on July 2021); f) Training on Photography (photo taken on May 2021) 
Gunungkidul Branch and development activities for Small and Medium Enterprises (MSMEs) are intended to support funding for various accommodation and amenity facilities. The implementation of the CSR program from BPD Bank is now increasing the community's enthusiasm to start opening business opportunities or MSMEs, such as various traditional Srumbung snacks, cafes, and other business ventures, as well as homestays and food stalls.

On the other hand, the growth of artistic culture in Srumbung has fostered a public interest in developing Gunung Ireng batik, which features a black stone pattern made of local andesitic thin sections (Figure 4.a; Figure 4.b). This is consistent with the government's policy of the district, namely one village one product (OVOP), which has developed effectively in every village. Another program that has also increased the number of MSME businesses is the Proud Shopping Program at Neighborhood Shops, where every visitor is obliged to participate in maintaining the local community's economic sustainability.

Visitors can now order kinds of menus prepared by the management (Figure 4.c; Figure 4.d). There are complete menus of (1) Kembul Bujono (break bread fiesta), (2) Ingkung Sego Gurih or Wuduk'an Menu (dish of savory rice with a whole chicken), (3) Complete Ireng Special Menu (consisting of Black (ireng)/red (abang), Gudeg/Gulai Manggar/Jantut (curry jackfruit/coconut flower/banana nut, with Gunung Ireng's Fish or Baked Chicken), (4) Indonesian Banquets (adjustable, usually for wedding dishes), (5) Complete menu of firecrackers, (6) menu of Baked Rice with Puthul's stir fry (only served in the rainy season), and (7) menu of red rice with Gunung Ireng's green chili, a buffet with various menus that visitors can choose from; various local snacks from Gunung Ireng, such as ungkrung chips, various kinds of crackers, various preparations made from Gunungkidul cassava, and others. Various hot drinks are also available, such as giras coffee, gedrey and geceng (a kind of spiced drink), and other cold drinks. Visitors who enjoy the sunrise and the milky way can get welcome coffee and soup on Sunday Mornings after they pay Rp. 10,000 per person for the ticket. On Sunday mornings, the community's traditional market sells various kinds of snacks and souvenirs.

Public facilities that have been successfully added during the activity are Wi-Fi and signboards (Figure 5). Microtik Unlimited Wi-Fi is used to support the needs of visitors and administrators. They get free internet facilities from the ticket payment, and they use it to upload their various activities on Gunung Ireng on their social media. There has been an uploader on the official website of Gunung Ireng of http://gununngireng.com (provided by the managers) to document all activities held at Gunung Ireng. Moreover, there is Primadonna Gunung Ireng, which is a natural museum of the ancient volcano. Several signboards have been installed at the geotourism destination. Those signboards explain the geology and history of the formation of each geotope, which consists of 7 stop sites. Some signboards are also installed along the road to Gunung Ireng to make it easier for first-time visitors, those from out of town, or those from abroad to reach it. Various signboards have also been installed as an effort of cultural and environmental conservation activities, namely the signboards of The Sunan Kalijogo's steps in propagating Islam on Gunung Ireng and the signboards of the local cultural heritage.

Providing sufficient provisions on geotourism guidance (Figure 6.a; Figure 6.b; Figure 6.c), website and the operating systems (Figure 6.d), social networking and motivation (Figure 6.e), and photography (Figure 6.f) have not succeeded optimally. A thorough evaluation of the training techniques that have been carried out is needed because most training does not run well and effectively. Other activities, such as providing accommodation in the form of conventional lodging and amenities require more time. A CSR program is available but it is insufficient for implementation. The last hope is proposed to the Yogyakarta Privileges Fund.

It is challenging to develop community-based geotourism at Gunung Ireng instantly. This is indicated by the number of failures in both paid and unpaid training efforts, which may be caused by the limited time they have or an inability to digest the knowledge provided. The impatience of the companion will be detrimental to all parties. The companion's firmness in pioneering and regulating all activities in the community is needed because not all levels of society have understood their vision, mission, and goals in developing their destination.

Most people are unable to emulate the principles of successful entrepreneurs who can put their money on the table, spin it, leave it; then wait until it is finished. This is how the community feels while developing their destination into a geotourism area, most of which only sell or exhibit stones, which they are unsure how to explain to the interested visitors. On the other hand, they can't mine it so they make money faster by regulating conservation efforts. The results will be achieved more quickly by bringing in investors. It will immediately be eye-catching. However, local people will not reap the benefits. Most will be as the workers in their land. The solution is to maintain continuity of the assistance so that the community is motivated to continue fighting while improving management capabilities It is because developing community-based 
geotourism has environmental, cultural, and economic conservation purposes.

Furthermore, the patience of the managers is often tested even by people around them. Some people's indifference, apathy, distrust, self-seeking, jealously, and greed play a role in determining the sustainability of the management. This assistance will be a separate force for managers to manage themselves, allowing them to determine the course of their management. It will also give birth to trust in all partners, resulting in mutual dependency and protection. All parties must work together to shape such an environment so that geotourism destinations can be actualized and conservation measures can be obtained.

\section{CONCLUSION}

Gunung Ireng has a specific interesting geological destination on Tertiary Submarine Paleovolcano. The place is unique because it is a miniature of an ancient volcanic lava dome located in the middle of an ancient underwater caldera. Community-based geotourism has been developed to conserve the environment, culture, and economy so that attractions, activities, amenities, and accommodations are described then prepared. The managers and mentors need five basic elements: a sense of belonging, fighting power, responsibility, trust, and cooperation. It requires a lot of effort to make it happen in terms of managers, mentors, and local communities. However, this step must be taken so that the descendants can feel its sustainability as long as possible.

\section{ACKNOWLEDGMENT}

Special thanks to the Directorate of Research and Community Service, Directorate General of Research and Development Strengthening, Ministry of Research and Technology for the grant following the Community Service Program Assignment Agreement Number 103/SP2H/PPM/2020, February 28, 2020. Many thanks are also addressed to the Gunungkidul Regional Planning, Research and Development Agency, Kapanewon Patuk, Pengkok Village, and in particular, the management of Gunung Ireng Geotourism destination for their generous supports in carrying out all these community service activities. Lastly, many thanks are also aimed at the Institute for Research and Community Service IST AKPRIND Yogyakarta for granting the permit to conduct its activity.

\section{REFERENCES}

Anonim (2017). Standar Teknis Inventarisasi Keragaman Geologi dan Identifikasi Warisan Geologi. Bidang Geosains Pusat Survei Geologi, Pusat Survei Geologi-Badan Geologi. Bandung, $16 \mathrm{p}$

Anwar, S., \& Barlian, E. (2019). The geodiversity potential of Tanah Datar District developing into a geotourism asset as a geopark in Indonesia.
In IOP Conference Series: Earth and Environmental Science (Vol. 314, No. 1, p. 012051). IOP Publishing.

Bentivenga, M., Cavalcante, F., Mastronuzzi, G., Palladino, G., \& Prosser, G. (2019). Geoheritage: the Foundation for Sustainable Geotourism. Geoheritage, 11, 1367 - 1369.

Blessia, S. A., Mulyaningsih, S., Tania, D., \& Heriyadi, N. W. A. A. T. (2019). Vulkano-Stratigrafi Gunung Ireng, Desa Pengkok, Kecamatan Patuk, Kabupaten Gunungkidul-DIY. Jurnal Teknomineral, 1(1), 24-33.

Dipowiguno, A. P., Setiawan, V. E., Arifin, A. S., \& Kusworo, (2020). A. Geological History of Natuna Island: Geodiversity, Geoheritage, and Sustainable Development Based on Geodiversity Inventory and Geoheritage Assessment.

Dowling, R. K., \& Newsome, D. (2010). Geotourism a global activity. Goodfellow Publishers Limited.

Mulyaningsih, S., \& Sanyoto, S. (2012). Geologi Gunung Api Merapi sebagai Acuan dalam Interpretasi Gunung Api Komposit Tersier di Daerah Gunung Gede Imogiri Daerah Istimewa Yogyakarta. In Prosiding Seminar Aplikasi Sains \& Teknologi (SNAST) Periode III.

Mulyaningsih, S. (2016). Volcanostratigraphic Sequences of Kebo-Butak Formation at Bayat Geological Field Complex, Central Java Province and Yogyakarta Special Province, Indonesia. Indonesian Journal on Geoscience, 3(2), 77-94.

Mulyaningsih, S., Blessia, S. A., Tania, D., \& Heriyadi, N. W. A. A. T. (2019a). Studi Fasies Gunung Api Purba Gunung Ireng, Desa Pengkok, Kecamatan Patuk, Kabupaten Gunungkidul-DIY. Jurnal Teknomineral, 1(1), 15-23.

Mulyaningsih, S., Heriyadi, N. W. A. A. T., Tania, D., \& Suhartono, S. (2019b). Identifikasi Jelajah Geologi Gunung Api Purba Gunung Ireng Desa Pengkok, Kabupaten Gunungkidul. Jurnal Pariwisata, 6(2), 154-168.

Mulyaningsih, S., Heriyadi, N. W. A. A. T., Tania, D., \& Suhartono, S. (2019c). Identifikasi Jelajah Wisata Geologi Gunung Api Purba Gunung Ireng: Sisi Lain Gunung Api Purba Nglanggeran, Gunungkidul. Jurnal Pariwisata Terapan, 3(2), 136-153.

Mulyaningsih, S., Suhartono, S., Heriyadi, N. W. A. A. T., \& Tania, D. (2021). Pendampingan Kepemanduan Geowisata Kawasan Cagar Alam Geologi Gunungkidul: Menuju Kebangkitan" Thoughtful" Indonesia. Jurnal Abdi Masyarakat Indonesia, 3(1).

Permadi, Reza, Rachwibowo, P., Hidajat, W.K. (2014). Potensi Situs-situs Warisan Geologi di Area Kars Gunung Sewu sebagai Pendukung dan Peluang Pengembangan Geopark di Indonesia untuk Aset Geowisata Kreatif. Geological Engineering E-Journal, 6(2), 586-601. 
Permana, A.K. (2020). Penetapan Warisan Geologi Pondasi Dasar Dalam Pengembangan Geopark. Badan Geologi, Bandung,

Ríos, C. A., Amorocho, R., Villarreal, C. A., Mantilla, W., Velandia, F. A., Castellanos, O. M., \& Briggs, A. (2020). Chicamocha Canyon Geopark project: A novel strategy for the socio-economic development of Santander (Colombia) through geoeducation, geotourism and geoconservation. International Journal of Geoheritage and Parks, 8(2), 96-122.

Rizkyaputri, N. S. (2021). Blackstone: Aplikasi Augmented Reality untuk Jenis Batuan Gunung Ireng dalam Mendukung Pengembangan Objek Geo-Wisata (Undergraduate thesis, Institut Sains \& Teknologi AKPRIND Yogyakarta).

Simbolon, J. H., Blessia, S. A., Mulyaningsih, S., Tania, D., \& Heriyadi, N. W. A. A. T. (2019). Petrologi Batuan Gunung Api Gunung Ireng, Desa Pengkok, Kecamatan Patuk, Kabupaten Gunungkidul-DIY. Jurnal Teknomineral, 1(1), 1-14.

Tania, D., Mulyaningsih, S., \& Suhartono, S. (2020). Gunung Ireng Menuju Kawasan Cagar Alam Geologi (KCAG). Dharma Bakti, 115-124.

Yuliawati, A.K., Rofaida, R., Gautama, B.P., \& Hadian, M. (2019). Geoproduct Development as Part of Geotourism at Geopark Belitong 